\title{
Caspase Activators: Phytochemicals with Apoptotic Properties Targeting Cancer, A Health Care Strategy to Combat this Disease
}

\author{
Asma Saqib1, Sharath Pattar², Chandrakant S Karigar ${ }^{3}$, Shailasree Sekhar ${ }^{4, *}$ \\ 1'Department of Biochemistry, Maharani's Science College for Women, Palace Road, Bangalore, Karnataka, INDIA. \\ ${ }^{2}$ Department of Bioinformatics, Maharani's Science College for Women, Palace Road, Bangalore, Karnataka, INDIA. \\ ${ }^{3}$ Department of Biochemistry, Bangalore University, Bengaluru, Karnataka, INDIA. \\ ${ }^{4}$ Scientist, Institution of Excellence, Vijnana Bhavana, University of Mysore, Mysuru, Karnataka, INDIA.
}

\begin{abstract}
Context: Caspases, a family of cysteine-aspartic proteases have a pivotal role in apoptotic pathways. Their down-regulation is reported to induce inappropriate cell survival and enhanced carcinogenic potential. Screening of phytochemicals with a capacity to activate caspases enhancing apoptotic capacity has been proven to be effective anticancer agents. Objectives: This review consolidates data on phtochemicals traditionally used to treat cancerous conditions. The scientific validation of caspaseactivated apoptosis for this traditional application has been compiled. Methods: Internet assisted scientific literature was collected from Google, Google Scholar, ResearchGate and $\mathrm{NCl}$, restricted to publications from 1997 to 2019. Search terms 'caspases and cancer', 'assay of caspases', 'traditionally used medicinal plants', 'Kani tribes', 'plant extracts activating caspase', 'cytotoxicity assay', 'docking phytochemicals to caspase', 'technological advancement for anticancer therapy', 'clinical studies of plant extracts and phytochemicals' and 'herbal drugs approved by FDA' was included. Results: The compilation revealed significance of multiple experimental strategies, traditional research laboratory practices and advanced in silico molecular docking techniques in anticancer therapy. Technological advancement such as MALDI-TOF assisted phytochemical mediated protein target identification and designing promoter for caspases activation and synthesizing functionalized nano carriers for clinical studies has been included for identification of hit molecule and lead optimization. Eugenol and berberine were identified as phytochemicals with potential drug characteristics by both in silico and in vivo studies. Conclusion: The phytochemicals from important Kani tribal medicinal plants via in silico docking and in vivo studies identified could be explored at clinical trials.

Key words: Anticancer, Apoptosis-associated caspase assay, Advanced in silico techniques, $\mathrm{NCl}$, Kani tribes, HeLa cell lines.
\end{abstract}

\section{INTRODUCTION}

Caspases, cysteine-dependent aspartic-aciddirected endoproteases, participate in ordered processes such as inflammation and cell death, essential for the initiation and execution of apoptosis. Synthesized as catalytically inactive pro-caspases, they are activated upon apoptotic stimulus, such as death ligands or permeabilization of outer mitochondrial membrane. In 1992, the first member of this family was described in Caenorhabditis elegans var. Bergerac (Rhabditidae), as essential for developmental cell death and named as CED-3 homologue interleukin-1beta-converting enzyme. ${ }^{1}$ Genetic analysis identified two genes (ced-3, ced-4) for cell death execution (Figure 1). Cloning of ced-3 identified it to encode a protease with homology to mammalian interleukin1 beta-converting enzyme. The cleavage site for this enzyme in interleukin 1beta was after aspartic acid residue 116. It provided the first indication of cysteine proteases as crucial components of the cell death
Submission Date: 05-08-2019; Revision Date: 18-09-2019; Accepted Date: 14-04-2020

DOI: 10.5530/ijper.54.2s.60 Correspondence: Dr. Shailasree Sekhar Scientist, Institution of Excellence, University of Mysore, Mysuru-570006, Karnataka, INDIA.

Phone: +919480476031 E-mail: shailasree@ioe. uni-mysore.ac.in

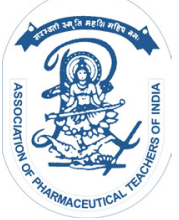

www.ijper.org 


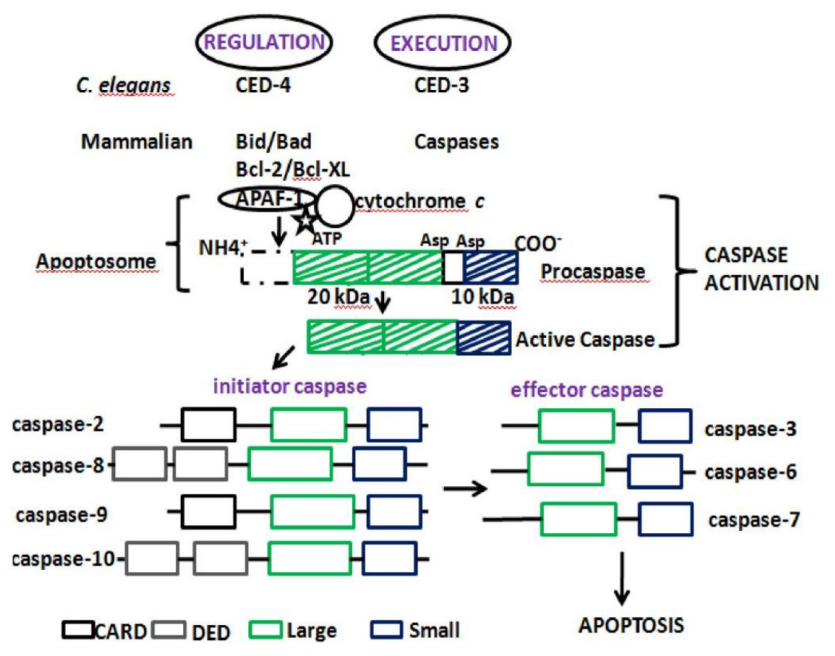

Figure 1: Caspase cascade in apoptosis.

CED-3 and CED-4 function to kill cells. APAF-1 protein contains (from the $\mathrm{N}$ terminal) a caspase recruitment domain. Upon binding cytochrome $\mathrm{c}$ and dATP, this protein forms an oligomericapoptosome upon binding to procaspase. The apoptosome binds and cleaves procaspase protein, releasing its mature, activate caspase. Alternative splicing results in several transcript variants encoding different caspase isoforms; initiator caspase- $2,-8,-9,-10$ and effector caspase- $3,-6,-7$.

CARD - The caspase recruitment domain; DED - Death-effector domain;

machinery. ${ }^{2}$ Use of caspase inhibitors resulted in cancer proliferation pointing to an essential role for caspases in execution of apoptosis. Subsequently, a growing family of cysteine proteases with homology to CED-3, designated as caspases (for cysteinyl aspartate-specific proteinase was reported. This family of enzymes comprises 11 members in humans and 13 in mammalians. ${ }^{3}$ They are classified based on reported apoptotic inducing capacity (caspase- $3,-6,-7,-8$ and -9 in mammals). Caspases with a role in human inflammation are caspases-1, $-4,-5,-12$. Those with a inflammatory role in mice are caspase-1, -11 and -12 . The functional role of caspase-2, -10 and -14 are less recognized. Apoptotic caspases are sub-classified by the site and mechanism of action as initiator caspases (caspase-2, -8, -9, -10) activated by dimerization on large multiprotein complexes or apoptotic executioner (caspase- $3,-6,-7$ ). They have various interaction with cellular proteins interacting with their prodomains leading to complex formation with adaptors. Caspase Recruitment Domain (CARD) is recognized in caspase- $1,-2,-4,-5,-9$. Death effector domain is in caspase- 8 and $-10 .^{3}$

Western Ghats, a major biodiversity hotspot along the Western coast covers an area of 159,000 sq km with $>15,000$ plant species. Several of them are endemic with potential medicinal value. Tribals dwelling in these remote areas of the forest cover of Western Ghats have used its flora since antiquity as first aid remedies. With increased prominence to explore traditional knowledge and ethnobotanical studies, validating traditional use by presenting scientific data has offered a route to develop novel drugs.

The Agasthyamalai hills, the mountain range in Kerala state of the Western Ghats, houses the indigenous Kani tribe. They are traditionally nomadic population of almost 25,000 individuals. This population meets their healthcare needs by preparations based on traditional knowledge using non-timber minor forest produces. A study of Xavier et al. ${ }^{4}$ identified and reported use of forest produces by these tribal documented through interviews of the Kani traditional healers. The nontimber produce could be used in fresh or dried state. Some of the preparations included a single herb or use of a combination of more than one in some of their preparations for a single or multiple ailments. A high degree of consensus among the tribal healers for use of a particular plant indicated presence of a consortium of phytochemicals that could be attributed to its medicinal property.

An increased global interest in identifying pharmacological potent compounds as preventive medicine without side effects has warranted attention. There are recommendations to increase consumption of foods rich in bioactive components for overall maintenance of health. Mankind, through trial and error, has found medicinal properties in seeds, barks, roots and leaves of certain plants and traditional knowledge has given clues to the discovery of these valuable drugs.

High-throughput ADMET screening provides an effective paradigm for filtering compounds for drug discovery process. The technique employed is based on the prediction of binding modes and binding affinities of each compound in the dataset by means of docking to an X-ray crystallographic structure. Various studies reported in literature stated the importance of dataset size such as 10,000 compounds using Flex and X, 19 44,000 compounds using Surflex20 and several others. Therefore, an alternative approach to eliminate unpromising compounds before docking by restricting the dataset to drug-like compounds is by filtering the dataset based on appropriate property and substructural features and by performing diversity analysis. These approaches can be highly effective in reducing the dataset to be docked.

\section{MATERIALS AND METHODS}

The present review was intended to consolidate extensive collection of scientific literature on plants traditionally used to treat cancerous conditions. The scientific validation of their anticancer activity via caspase-activated apoptosis for traditional application has been compiled. 
Internet assisted literature was collected from Google, Google Scholar, ResearchGate and NCI, restricted to publications from 1997 to 2017. Search terms 'caspases and cancer', 'assay of caspases', 'traditionally used medicinal plants', 'Kani tribes', 'plant extracts activating caspase', 'cytotoxicity assay', 'docking phytochemicals to caspase', 'clinical studies of plant extracts and phytochemicals', 'herbal drugs approved by FDA' and 'technological advancement for anticancer therapy' was included.

\section{Molecular Docking of Phytochemicals from Important Kani Tribe Medicinal Plants Swiss Autodock}

2Y1L

Caspase-8 of from Homo sapiens complex with DARP (dopamine releasing protein) in -8.4 was used for the study. $2 \mathrm{Y} 1 \mathrm{~L}$ has all the unique 4 protein chain and all the strict requirement for Asp at position P1 and has a preferred cleavage sequence of (Leu/Asp/ Val)-Glu-Thr-Asp-1-(Gly/Ser/Ala).

\section{Ligand preparation for docking}

A set 82 phytochemicals were selected from literature survey reported from traditional medicinal plants of Kani tribes ${ }^{4}$ recommended in the review by Xavier et al. ${ }^{4}$ as a possible source of potential new drugs. They were screened for caspase- 8 activation via in silico technology. A total of 16 of them exhibited drug likeliness and selected for docking. Drawing window of chemsketch was applied to obtain 3D-coordinates. Gross biological capacity of Lipinski rule 5 was evaluated. Further drug likeness and drug score was estimated.

\section{Molecular docking}

In silico docking was performed using the Swiss Doc of the Lead IT software. Pubchem was used to download ligands. Addition of $\mathrm{H}$-atoms as required was carried out. The molecular models were built. A strategy of steepest descent approximation by running 1000 cycles of energy was applied in this process. The Chimera tool UCSF 1.6.2 was used at a gradient of 0.02. The AMBERff99SB Force field procedure was also applied. The charges of Gastiger were added to the ligands. The Mol2 format was applied to save them. The resulting product was uploaded into the docking toll of Swiss Doc from the Lead IT software.

\section{Target protein minimization}

The 2Y1L protein was loaded into the prepared molecule module Bio solve IT software. For experimental initiation Lead IT chain A of the protein was prepared and selected for docking procedure. The binding pocket of caspase- 8 comprised site of interest. The binding energy of this site was minimized. The binding pocket amino acid atomic coordinates were converged. The 2Y1L protein was now ready for docking.

\section{Active Site prediction}

The binding pockets of $2 \mathrm{Y} 1 \mathrm{~L}$ were identified for the binding site analysis. The largest binding pockets were selected for docking studies. A search was carried out for possible binding residues of receptor. The results were applied in our study.

\section{Swiss ADME was applied for drug likeliness evaluation}

Swiss ADME analysis for the ligands was assessed.

\section{In vivo evaluation of in silico observations}

HeLa cell lines were procured from National Centre for Cell Science (NCCS), Cell Repository, Pune. The procured cell lines were approved by NCCS ethics committee. HeLa cells were maintained in Eagle's Minimum Essential Medium (EMEM). They were supplemented with $10 \%$ fetal bovine serum (FBS). The cells were incubated in $5 \% \mathrm{CO}_{2}$ at $37^{\circ} \mathrm{C}$.

\section{Confocal Laser Scanning microscopy}

For fluorescence microscopy HeLa cells were incubated in 6-well plates at an initial cell density of $1 \times 10^{5}$ cells $/ \mathrm{mL}$ were grown on $12 \mathrm{~mm}$ glass coverslips. When cell density reached $80-90 \%$ confluence, cells were treated with eugenol $(500 \mathrm{~m} / \mathrm{mL})$ and berberine $(500 \mathrm{~m} / \mathrm{mL})$ procured from Sigma Aldrich-Merck Pvt., Ltd, Bengaluru, India for the indicated times (24 and 48h). At the time intervals (24 and 48hr) cells were washed once with PBS (145 mM NaCl, $7.5 \mathrm{mM}$ $\mathrm{Na}_{2} \mathrm{HPO}_{4}, 2.8 \mathrm{mM} \mathrm{NaH}_{2} \mathrm{PO}_{4}$. Additional medium was then removed with filter paper. The CaspGLOW ${ }^{\mathrm{TM}}$ Fluorescein active Caspase- 8 staining kit was procured for detection of active Caspase- 8 in living cells and the manufacturers' protocol was followed. The FITC (fluorescent marker)-conjugated caspase- 8 inhibitor, IETD-FMK permeabilized the cells. It bound to cytosolic active caspase- 8 irreversibly. FITC on the IETD-FMK was detected by Confocal Laser Scanning Microscope, LSM710 (Carl Zeiss, Germany).

\section{RESULTS}

The search identified an essential role for caspaseactivated apoptosis and its up-regulation leading to cancer suppression property. The compilation revealed significance of multiple experimental strategies of both 
traditional research laboratories practice and advanced in silico molecular docking techniques in anticancer therapy. Technological advancement applied in screening of a set of phytochemicals via MALDI-TOF assisted phytochemical mediated protein target identification with designing promoter for caspases activation and synthesizing functionalized nano carriers for clinical studies has been included. Construction and maintenance of natural product library, albeit, compiled information of microbial, plant, marine or sources composed of crude extracts, semi pure mixtures or single purified natural product has been reported to carry a distinctive advantage. ${ }^{5,6}$ Additionally they could provide links to available literature on phytochemicals reported from various research laboratories with potentially more chemical interactive sites for computational studies. This could facilitate their introduction into clinical trials for hit identification and lead optimization leading to developing anticancer drugs with lower effective dosage. ${ }^{7}$

\section{Caspases and Cancer}

A note on evidence for down-regulation of caspases resulting in cancerous conditions has been detailed (Table 1). Caspase-8, an initiator caspase enzyme, has a role in extrinsic death receptor pathway, with obligatory role in apoptosis have a putative role in cancer suppression. ${ }^{8}$ Silencing of CASP8 gene by deletion or methylation of its promoter was reported in tumors

\begin{tabular}{|c|c|c|}
\hline Caspases & Cancer & Reference \\
\hline$\downarrow C A S P 8$ & $\begin{array}{c}\text { Neuroblastomas (children) } \\
\text { Advanced gastric invasive } \\
\text { colorectal } \\
\text { Head and neck } \\
\text { Hepatocellular } \\
\text { Lung and breast cancer } \\
\text { cell lines }\end{array}$ & $\begin{array}{c}\text { Teitz et al. }{ }^{9} \\
\text { Soung et al. } .^{12} \\
\text { Kim et al. }{ }^{11} \\
\text { Soung et al. } .^{12} \\
\text { Soung et al. } .^{12}\end{array}$ \\
\hline$\downarrow$ Caspase-10 & $\begin{array}{c}\text { Lung and breast cancer } \\
\text { cell lines }\end{array}$ & Kischkel et al..$^{73}$ \\
\hline$\downarrow$ Caspase-2 & Gastric & Yoo et al. ${ }^{74}$ \\
\hline$\downarrow$ Caspase-9 & Colorectal & Palmerini et al. ${ }^{75}$ \\
\hline$\downarrow$ Caspase -6 & Gastric & Yoo et al. ${ }^{74}$ \\
\hline $\begin{array}{l}\downarrow C A S P 7 \\
\downarrow \text { Caspase-7 }\end{array}$ & $\begin{array}{l}\text { Colorectal } \\
\text { Head and neck } \\
\text { Colorectal } \\
\text { Gastric }\end{array}$ & $\begin{array}{c}\text { Soung et al. }{ }^{12} \\
\text { Soung et al. } .^{12} \\
\text { Palmerini et al. }{ }^{75} \\
\text { Yoo et al. }{ }^{74}\end{array}$ \\
\hline $\begin{array}{l}\downarrow \text { Caspase-3 } \\
\uparrow \text { Caspase-3 }\end{array}$ & Breast & $\begin{array}{l}\text { Devarajan et al. } \\
\text { Nakopoulou et al. }{ }^{77}\end{array}$ \\
\hline
\end{tabular}

$\uparrow=$ activated/improved activity/ upregulated

$\downarrow=$ inhibited/ downregulated

Italized = gene; unitalicized $=$ enzyme; and cell lines pediatric cancer. An amplified MYCN oncogene transcript with elevated levels of its protein was reported. ${ }^{9,10}$ A CASP8 gene mutation due to stop codon modification and Alu repeat to its site was observed in oral cavity cytolytic $\mathrm{T}$ lymphocytes of human squamous cell carcinomas. A relatively low frequency of CASP8 mutations have been reported in colorectal and gastric cancers. In patients suffering from hepatocellular carcinoma, a somatic frame-shift mutation (1225-1226delTG) was reported in nine of the 69 patients. ${ }^{11,12}$ Thus, caspase- 8 enzyme alterations resulted in decreased capacity to initiate apoptosis in these cancerous conditions.

Caspase activity assays include a variety of techniques with specific reagents by ELISA using fluorescent or luminescent groups for measurement of their activity. They provide the vital information on its cascade in apoptotic pathway. As each of these techniques has their own advantages and disadvantages, it has been recommended to use at least two complementary assay methods during such studies (Table 2). ${ }^{13}$

\section{Plants and Phytochemicals against Cancer}

The World Health Organization (WHO) estimates cancer deaths (to the tune of $30 \%$ ) to dietary habits and lifestyles (physical inactivity, smoking and alcohol consumption). In the year 2012 alone, deaths related to cancer were estimated to be 8.2 million. The condition of lung cancer at $19 \%$ was leading the statistics. Harmful compounds such as polycyclic amines, polycyclic aromatic hydrocarbons, $N$-nitroso compounds from nitrite and reactive oxygen species from heme iron induce increased cell proliferation and DNA damage. ${ }^{14}$

The proof is the decades of observation and epidemiological studies suggesting dietary interventions in preventing and decreasing the onset or even reversing chronic disease conditions. ${ }^{15}$ Plant diet finds application due their ability to re-sensitize treatment of resistant cancer cells. ${ }^{16}$ Dietary bioactive compounds inducing apoptosis via extrinsic / death receptor pathway of apoptosis reviewed ${ }^{17}$ are listed (Table 3, Figure 2a, 2b).

Questioning the safety of anticancer drugs like synthethic cisplatin and cyclophosphamide with several undesirable side effects, the search for anticancer agents from plant sources, modern science has turned to it for exploitation of the vast phytochemicals to therapeutic targets. ${ }^{18-21}$ In many instances, the cancerous condition was reported as 'hard swellings', 'abscesses', 'calluses', 'corns', 'warts', 'polyps', or tumors. ${ }^{22}$ The United States initiated extensive plant collection program through National Cancer Institute (NCI) as a part of the National Institute of Health (NIH) in 1957. A total of 1,14,000 extracts 


\section{Table 2: Assays to detect active caspase induced by apoptotic stimuli.}

\begin{tabular}{|c|c|}
\hline $\begin{array}{c}\text { Fluorogenic and } \\
\text { chromogenic assay } \\
\text { ELISA }\end{array}$ & $\begin{array}{l}\text { Estimation of cleaved substrate products and estimating fluorogenic or chromogenic leaving groups } \\
\text { Substrates used: aminofluorocoumarins } N \text {-acetylaspartyl-glutamylvalinylaspartyl-7-amino-4- } \\
\text { trifluoromethyl coumarin (DEVD-AFC) for caspase-3 and -7; N-acetylvalinyl-glutamylisoleucylaspartyl- } \\
\text { AFC (VEID-AFC) for caspase-6; } \\
\text { Advantages: } \\
\text { - Obtaining temporal and spatial information about caspase activation } \\
\text { Allows estimation of multiple activities in replicates } \\
\text { Disadvantages: } \\
\text { Non-specificity as DEVD-AFC, preferred substrate for caspase-3 is cleaved by caspases-1, }-2,-4,-6,-7 \text {, } \\
-8,-10 \text { and }-14 \\
\text { Apo-ONE }{ }^{\mathrm{TM}} \text { (Promega, Madison, WI) homogenous caspase-3/7 kit -estimation based on release of } \\
\text { rhodamine } 110 \text { from peptide bound substrate } \\
\text { PhiPhiLux }{ }^{\mathrm{TM}} \text { (Oncolmmunin, Gaithersburg, MD), peptide with caspase cleavage site tagged with } \\
\text { fluorescent moiety, rhodamine } 110 \text { on one end and a quencher on the other, generating a fluorescent } \\
\text { signal upon cleavage of the peptide that separates the flurophore and quencher } \\
\text { Disadvantage: } \\
\text { The requirement to load the peptide into cells prior applying an apoptotic stimulus }\end{array}$ \\
\hline Immunoblotting & $\begin{array}{l}\text { - Using sera for caspase cleavage products, the anti-neoepitope antibodies } \\
\text { Procaspase } 3 \text { and } 6 \text { rabbit polyclonal antibodies from Cell Signaling Technology (Beverly, MA); } \\
\text { monoclonal antibodies to poly(ADP)-ribose polymerase (PARP) and cleaved caspase-3 antibodies from } \\
\text { Sigma (St. Louis, MO) } \\
\text { Advantages } \\
\text { The high quality antibodies recognize caspase cleavage products making it possible to detect } \\
\text { procaspase cleavage during apoptosis } \\
\text { It provides important evidence for caspase activation during apoptosis } \\
\text { Disadvantages } \\
\text { - Some of the initiator caspases gain enzymatic activity even without cleavage. Thus it is possible for } \\
\text { caspases- } 8 \text { and/or } 9 \text { detecting in immunoblots. } \\
\text { The level of caspase cleavage might not reflect the quantity of activated caspase as it is dependent on } \\
\text { the stability of cleavage products } \\
\text { Assessing the appearance of a band at a molecular weight or disappearance of a band at a molecular } \\
\text { weight is difficult is the immunological reagent recognizes } 10 \text { bands on a blot. } \\
\text { The cleavage of a particular substrate does not necessarily indicate the activated caspase. The cleavage } \\
\text { of a particular substrate, PARP, a classically caspase- } 3 \text { substrate, is cleaved by other caspases, } \\
\text { caspase- }-3,-7,-8,-9 \text { and }-10 \text { in vitro and by caspases } 7 \text { and or/- } 9 \text { in cells deficient of caspase- } 3 \text {. }\end{array}$ \\
\hline $\begin{array}{l}\text { Immunofluorescence } \\
\text { or flow cytometry }\end{array}$ & $\begin{array}{l}\text { - Using antibodies that recognize the active conformation of caspase-3, IETD (Cell Signaling } \\
\text { Technologies), the sequence that becomes the C-terminal of the caspase-3 large subunit when } \\
\text { procaspase } 3 \text { is cleaved by initiator caspase. } \\
\text { Using anti-neo-epitope antibodies that recognizes C- or N-terminal amino acids } \\
\text { Advantages } \\
\text { - Quantitative data regarding the percentage of cells stained could be obtained } \\
\text { - Specificity of the reagents used aids in assessing with certainty activation of a particular caspase } \\
\text { Disadvantages } \\
\text { - There is a lack of availability of conformation-sensitive antibodies to most of the active caspases } \\
\text { A potential cross-reactivity of anti-caspase neoepitope antibodies with other polypeptides cleaved during } \\
\text { apoptosis containing similar sequences }\end{array}$ \\
\hline $\begin{array}{l}\text { Affinity labeling for } \\
\text { immunoblotting, } \\
\text { fluorescence } \\
\text { microscopy and flow } \\
\text { cytometry }\end{array}$ & $\begin{array}{l}\text { - Using covalent modification of the caspase active site with a substrate-like molecule with an inhibitory } \\
\text { group and a reporter moiety } \\
\text { Acyloxymehylketones (aomks) with reporter moiety (biotin labeled streptavidin; fluorescein; } \\
\text { 2,4-dinitrophenol) attached to the amino acid immediately upstream of the scissile aspartate (the } \\
\text { P2 amino acid) exposed to solvent and with the capacity to accommodate a bulky substituent upon } \\
\text { inhibition binding the caspase or at the N-terminus of the peptide. The biotin-X-VAD(OMe)-fmk and } \\
\text { zEK(bio)D-aomk from Calbiochem and the Osaka Peptide Institute (Osaka, Japan) respectively are used. } \\
\text { Advantages } \\
\text { - Uniquely capable of identification of the caspases activated in the cells at the onset of apoptosis } \\
\text { Can be used for studying caspases that lack anti-caspase antibodies } \\
\text { Disadvantages } \\
\text { The reagents are expensive and require custom synthesis } \\
\text { - Sometime endogenously biotinylated polypeptides could be detected or co-purified } \\
\text { Not all caspases react with affinity ligands.zEK(bio)D-amok readily labels caspases } 2,3,6,7 \text { and -9 but } \\
\text { not activated caspase-8 }\end{array}$ \\
\hline RT-PCR & 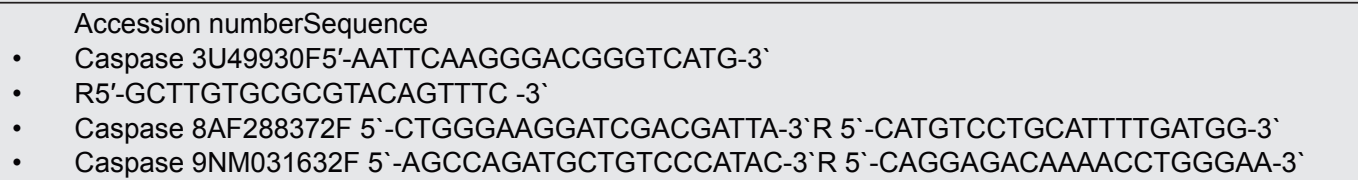 \\
\hline
\end{tabular}




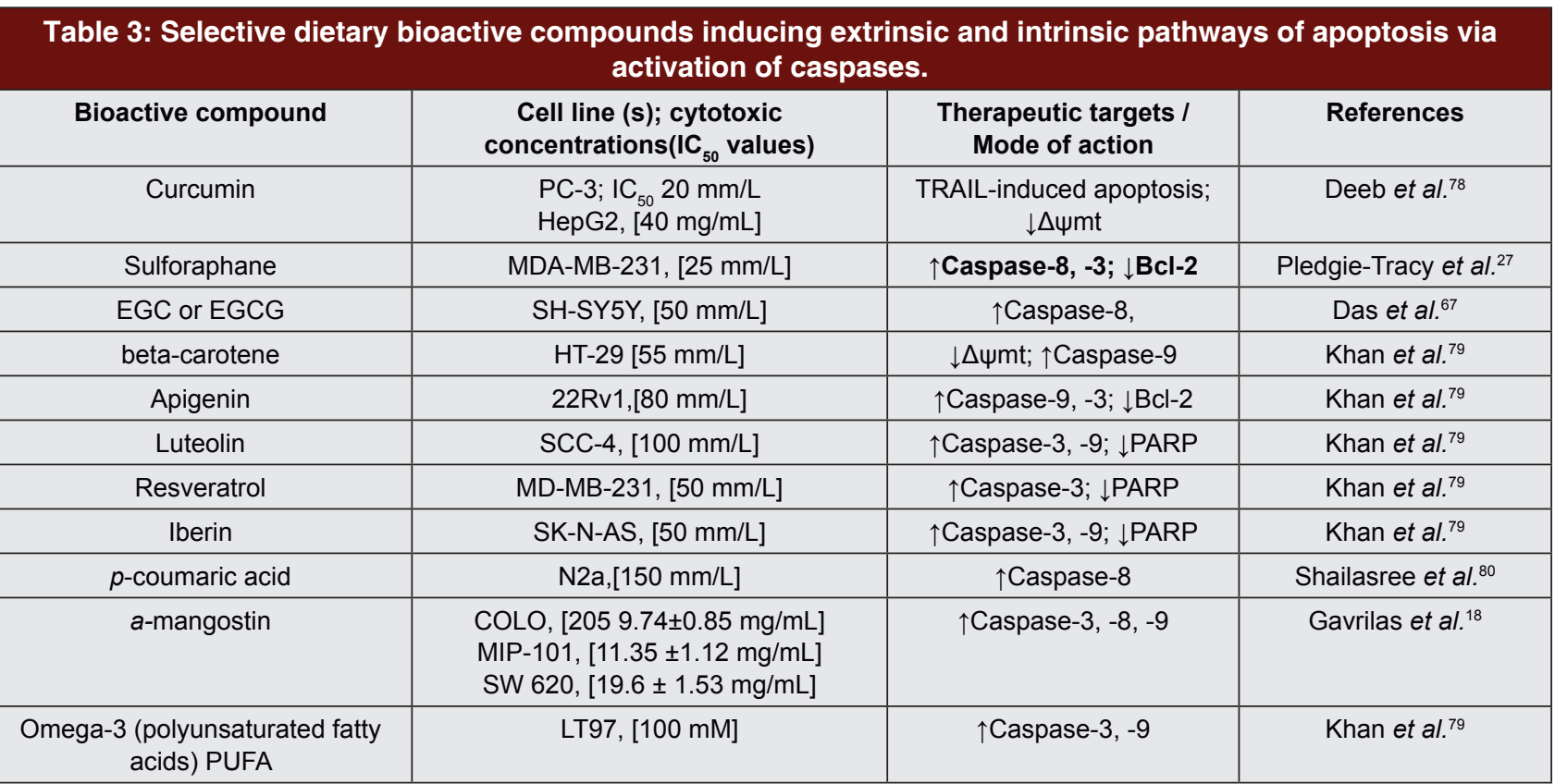

$\Delta \psi \mathrm{mt}$ - mitochondrial membrane potential; PARP: poly ADP ribose polymerase; TRAIL:TNF-related apoptosis inducing ligand $\uparrow=$ activated/improved activity/ unregulated<smiles>O=c1cc(-c2ccc(O)cc2)oc2cc(O)cc(O)c12</smiles><smiles>CS(=O)CCCCN=C=S</smiles>
Sulforaphane<smiles>O=C(NC1Cc2c(O)cc(O)cc2OC1c1cc(O)c(O)c(O)c1)c1cc(O)c(O)c(O)c1</smiles>

Epigallocatechin gallate<smiles>COc1cc(/C=C/C(=O)CC(=O)/C=C/c2ccc(O)c(OC)c2)ccc1O</smiles><smiles>O=c1cc(-c2ccc(O)c(O)c2)oc2cc(O)cc(O)c12</smiles><smiles>Oc1ccc(/C=C/c2cc(O)cc(O)c2)cc1</smiles>

Resveratrol<smiles>COc1c(O)cc2oc3cc(O)c(CC=C(C)C)c(O)c3c(=O)c2c1CC=C(C)C</smiles>
p-coumaric acid

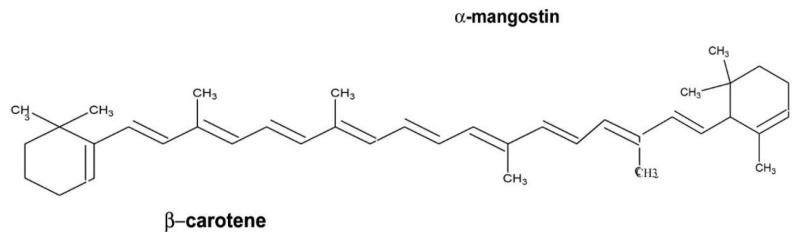
$\beta$-carotene<smiles>CS(=O)CCCN=C=S</smiles>

Figure 2b

Figure 2a, 2b: Dietary phytochemicals inducing caspase-activated apoptosis.

from around 35,000 plant samples for anticancer activity were screened. By 1991, 28,800 plant samples from over 20 countries were catalogued for chemotherapeutic capacity initially screened in vitro against human cancer cell lines. ${ }^{22}$ The survey carried out showed that above $60 \%$ of clinically viable anticancer drug reported were of natural origin or were modeled on natural product parents. The seven plant derived anticancer drugs with
US Food and Drug Administration (FDA) approval for commercial production were taxol from Taxus brevifolia, vinblastine and vincristine from Catharanthus roseus, etoposide and teniposide from Podophyllum peltatum, topotecan from Camptotheca acuminate and irinotecan from Camptotheca acuminate (Table 4). The most successful discoveries are the vinca alkaloids (vinblastin and vincristine) from Catharanthus roseus. ${ }^{23}$ 
Table 4: Plant extracts and compounds (selective) that were screened against NCl-60 Cancer cell panel, information referring $\mathrm{NCl}$ website.

\begin{tabular}{|c|c|}
\hline Plant extracts/compounds & Reported properties in NCI Website \\
\hline Mistletoe extracts (PDQ®) & Cancerous conditions \\
\hline Eribulin mesylate (Halaven) & Breast and lung cancer \\
\hline Crizotinib (Xalkori®) & Non-small cell lung cancers \\
\hline Taxol & Breast and ovarian cancers \\
\hline Ibrutinib & Effective against Graft-Versus-Host Disease \\
\hline Gardasil 9 & HPV Types ( HPV types 6, 11, 16, 18, 31, 33, 45, 52 and 58) ${ }^{\star}$ \\
\hline Velcade® & Multiple Myeloma, blood cancers and solid tumors \\
\hline Sonidegib & Advanced Basal Cell Carcinoma \\
\hline Vinblastine and vincristine & Leukemia, bladder and testicular cancers \\
\hline Etoposide and teniposide & Small-cell lung cancer, testicular cancer, lymphomas \\
\hline Topotecan & Ovarian and small-cell lung cancers \\
\hline Irinotecan & Metastatic colorectal cancer \\
\hline
\end{tabular}

*HPV types 6 and 11 are low-risk types that do not cause cancer but can cause warts on or around the genitals, anus, mouth, or throat. 16 and 18 are responsible for approximately 70 percent of all cervical cancers and HPV types $31,33,45,52$ and 58 are responsible for another 20 percent of cervical cancers.

\section{Clinical Trials}

Paclitaxel (taxol/ taxane) from Taxus brevifolia L. with reported ability to block mitosis, disrupt microtubule and spindle formation and inhibit translational machinery is in Phase I-III clinical use. It is tested against breast-, non-small lung cancer, ovarian- cancer and Kaposi sarcoma. Nano-particles, nanochealtes and nanoliposomes are being developed as alternate form of administration of this drug. . $^{14,24,25}$ Sulphoraphane in cruciferous vegetables inhibits growth in breast cancer has been taken up for clinical trials. Administration of cruciferous vegetable preparations orally with sulphoraphane is underway. ${ }^{26-28}$ Podophyllotoxin isomer, epidophyllotoxin from Podophyllum peltatum L. with pro-apoptotic capacity interfering with cell cycle has been tested for clinical trials against lymphomas and testicular cancer. ${ }^{29,30}$ Vinca alkaloids from Catharanthus roseus G. Don with apoptotic capacity, bind beta-tubulin and destabilize microtubule, induce cell cycle arrest have been incorporated in clinical trials. Vincristine for lymphomas, sarcomas and leukaemias; vinblastine for testicular cancer, Hodgkins disease and lymphomas; ${ }^{30-33}$ vinorelbine for Phase I-III against non-small cell lung cancer, ${ }^{31,33}$ vindesine against acute lymphocytic leukaemia; ${ }^{33}$ vinflunine in Phase III clinical trials against solid tumors and Vinflunine in Phase III clinical trials against solid tumors. ${ }^{29}$ Isoflavonoid, pomiferin isolated from Maclura pomifera and Dereeis malaccensis exhibit antioxidant activity. It inhibits histone-deacetylase. It is reported to be cytotoxic to MDA-MB-231-breast, NCI-H23- lung, ACHN - kidney, PC-3 - prostate, HCT-15 -colon human cancer cell lines, LOX-IMVI - Melanoma and MDA-MB-231breast cancer cells. ${ }^{32,33}$ Epigallactochin-3-gallate derived from catechin rich in green tea is in Phase I trial for oral administration related to prostate cancer. ${ }^{33,34}$ Combretastatin A-4 phosphate is a water soluble analogue of combrestatin from Combretum caffrum exhibited anti-angiogenic capacity and has been in early trails against cancer development. ${ }^{14}$ Roscovitine derived from olomucine isolated from Raphanussativus L. has been tested for in Phase II clinical trials in Europe due to its ability to inhibit cylin dependent kinases and inhibit cell cycle progress. ${ }^{35}$ Flavopiridol based on rohitukine (isolated from Dysoxylum binectariferum Hook. f.) structure, a synthetic flavonoid is being tested in clinical trials of Phase I and Phase II for leukaemias, solid tumors and lymphomas. ${ }^{35}$ Opium (isolated from Papaver sominiferum) derived noscapine is being tested in Phase I and Phase II trials and nanotechnology assisted drug administration is being experimented due to its limited water-solubility. ${ }^{24}$

\section{Herbal Mixtures}

The anticancer effect of popular Japanese and Chinese herbal formulation (Minor Bupleurum Combination), also known as Xiao Chai Hu Tang (China) or Sho-saiko-to (Japan) is attributed to herbal components, baical skullcap (Scutellaria baicalensis), baicalein, glycyrrhizin (licorice root), saikosaponins, ginsenosides, wogonin and gingerol. It has been in use for nearly 3000 years. ${ }^{36,37}$ Tanaka et al..$^{38}$ reported promising results in patients with colorectal adenomas.

\section{Medicinal Plants Inducing Caspase Activated}




\section{Apoptosis}

The search for novel natural compounds by the natural product research ${ }^{39,40}$ has kept alive natural product discovery. ${ }^{41}$ There is also reported use of various standardized extracts or fractions of single or mixed herbs with anticancer effects as dietary supplements. ${ }^{42}$ Evaluation of potential cytotoxic anticancer agents leading to apoptosis of cancer cells, theoretically arresting their growth and spread of neoplasms has been adapted in many manuscripts. ${ }^{43-46}$

\section{Advanced in silico Techniques}

Comparative in silico and biotechnological techniques have been applied to develop optimal screening strategies of medicinal plants and phytochemicals for revealing their elusive mode of caspase-activated apoptotic activity.

\section{In silico docking}

Molecular assay via computational methodology of docking process finds application in drug discovery program involves ligand (small molecule) - protein X-ray crystallography structure. ${ }^{47}$ Compound from Alkanna tincotir, 5-methoxyangenylalkannin, exhibited arrest of cancer cell in the $\mathrm{S}$ and $\mathrm{G} 2 / \mathrm{M}$ phases inducing apoptosis. Docking (Surflex-Dock, Tripos, St. Louis, MO, USA) of its structure to caspase-9 (PDB code 2AR9) suggested formation of hydrogen bonds with hydroxyl groups of Asp-340 and Ser-339 at the active site. ${ }^{48}$ Binding of eucalyptol, phytochemical from cardamom to caspase-3 analyzed by Auto Dock Pyrx was reported with poly-pharmacological anticancer property. ${ }^{49}$ In another study, the 3D structures of neophytadine, nitrocyclohexane, octadecane and tetadecanoic acid were docked to caspase-3 receptor (PDB code 2X70). Nitrocyclohexane and neophytadiene with lower energy values specifically interact with the receptor supporting caspase-activated apoptosis. ${ }^{50}$ Quercetin docked with caspase-3 exhibiting a strong interaction and docking score of $-4.09 \mathrm{kcal} / \mathrm{mol}$ validates its anticancer activity. ${ }^{51} \mathrm{~A}$ set of 32 anticancer 3-aryl5-aryl-1,2,4-oxadiazoles docked to caspase-3 with precise correlations validating apoptosis via caspase- 3 activation. ${ }^{52}$ This combined assessment showed a good correlation between predicted and observed activity.

\section{Designing molecules of smaller size for activation of caspase-3 from procaspase-3}

Caspase-3, the executioner protein, is stored in its inactive procaspase- 3 form with zinc inhibiting it at low concentrations and has a safety catch, a triaspartic acid (DDD), blocking the isoleucine-glutamine-threo- nine-asapartate, ile-glu-thr-asp (IETD) site of proteolysis. A small promoter molecule, procaspase-3 activating compound, PAC-1, discovered by Putt et al. ${ }^{53}$ could directly interact with and cleave this catch promoting the cancer cell to apoptosis. A set 38 molecules with positive charge at physiological $\mathrm{pH}$, similar to piperazine nitrogen in PAC- $1,{ }^{54}$ were screened for their capacity to directly interact with safety catch DDD in procaspase-3. In silico using CDOCKER-a CHARMm-based MD docking algorithm tool of Discovery Studio was used. ${ }^{55}$ This study identified above cited molecules with a capacity to promote caspase-activated apoptosis in cancer cells. ${ }^{54}$

\section{Phytochemical mediated differential expression of protein targets}

Proteomics of apoptotic maslinic acid, a natural pentacyclictriterpene subjected to comparative proteomics and biotechnological studies revealed it capacity to down-regulate dUTP and stathmin. These are two proteins involved in induction of early $\mathrm{S}$ and $\mathrm{G} 2$ cell cycle arrest. ${ }^{55,56} \mathrm{~A}$ set of fourteen cytoskeleton proteins that were differentially expressed were reported. ${ }^{57}$ Apoptosis induced by maslinic acid has been correlated with caspase and c-Jun $\mathrm{N}$-terminal kinase activation. ${ }^{58}$ These combinatorial studies could provide opportunities for phytochemicals to be developed into site- and targetspecific anticancer agents. ${ }^{59}$

\section{Nano formulations for optimal activity}

Targeting phytochemicals and drugs to dedicated sites via functionalized nanoparticles has evolved as new standard in anticancer methods.

i. Functionalized nano carriers, folate-terminated polyrotaxanes (drug carrier) with dequalinium (compound for selective delivery of drug into mitochondria) with $101 \mathrm{~nm}$ size containing 18\% classic cytotoxic anticancer drug, doxorubicin (DOX) was tested against DOX resistant cancerous cells of breast - MCF-7 and MCF-7/Adrxenografts of nude mice. A caspase-9 and -3 dependent apoptosis via activation of $\mathrm{Bax}$, Bid and inhibition of Bcl-2 were reported. A six-fold intracellular uptake of DOX and a decreased drug efflux in comparison to free drug was reported. ${ }^{60}$

ii. A KLA peptide, D[KLAKLAK 2 modified with 2,3-dimethylmaleic anhydride (DMA) was combined with 1,2-distearoyl-sn-glycero-3-phosphoethanolamine (DSPE) and paclitaxel. It resulted in apoptotic paclitaxel nanodrug, DSPE-KLA-DMA (DKD) lipid. They could facilitate liposome internalization by reversing surface charge (-ve to $+v e)$ at extra- 
cellular $\mathrm{pH}$ of $\sim 6.8$ into lung cancer, A549 cells. Apoptosis (cytotoxicity, $86.7 \%$ ) via mitochondrial signaling pathway was evidenced by release of cytochrome c, increased caspase- 9 and -3 activities. ${ }^{61}$

iii. Liposomal assisted internalization of Anti-RNAs (antisense oligonucleotides, asOs) asOs initiates its binding and silencing of miRNAs with impaired invasion and proliferation of cancer. Overexpression of phosphatase and tensin homolog (PTEN), programmed cell death protein 4 (PDCD4) with activation of caspase $3 / 7$, an apoptotic mode of cytotoxicity was reported.$^{62}$ miRNAs are involved in all stages of colorectal cancer. ${ }^{63}$ Curcumin, resveratrol, quercetin, alpha-mangostin, Vitamin D, omega-3 PUFA have been reported with miRNA modulatory activity. ${ }^{18}$ Their anticancer capacity could be enhanced when entrapped in nanostructures detailed ${ }^{25}$ improving their antineoplastic effect.

Synergism of phytochemical, cannabinoids from Cannabis sativa $\mathrm{L}$. with cancer treatment drugs, temozolomide (chemotheraphy drug) has been commonly used in patients with glioblastoma. Cannabinoids could enhance efficacy of bicalutamide or docetaxel, standard drugs used in prostate cancer treatment. ${ }^{64}$

\section{Phytochemicals of Important Kani Tribe Medicinal Plants with Apoptotic Properties Activating Caspase-8: an in silico Study}

Kani tribal communities in Thodu hills of Kerala use non-timber minor forest products and preparations to meet their healthcare like for first aid remedies, to treat cough, cold, fever, headache, poisonous bites among others based on traditional knowledge. ${ }^{4}$ The present study was also initiated with an aim to identify phytochemicals reported in these plants with a capacity to activate caspases directing cancer cells towards apoptosis via in silico technology (Table 5). The data compiled and presented in this review includes phytochemicals (Figure 3) reported with potential anticancer activities find rare mention. ${ }^{65,66}$

\section{In vivo evaluation of in silico observations}

Eugenol and berberine were identified to exhibit a relatively higher caspase- 8 activating capacity (Table 5). The other phytochemicals did not exhibit this property. Hence Eugenol and berberine were identified for further studies for in vivo analysis. The activation of caspase- 8 has been reported to be a pre-requisite for apoptosis. Data generated by Confocal Laser Scanning Microscopy (CLSM) on activation of apoptosis by eugenol $(500 \mathrm{mg} / \mathrm{ml})^{67}$ and berberine $(500 \mathrm{mg} / \mathrm{ml})^{68}$ at said time intervals of 24 and $48 \mathrm{~h}$ (Figure 4) support

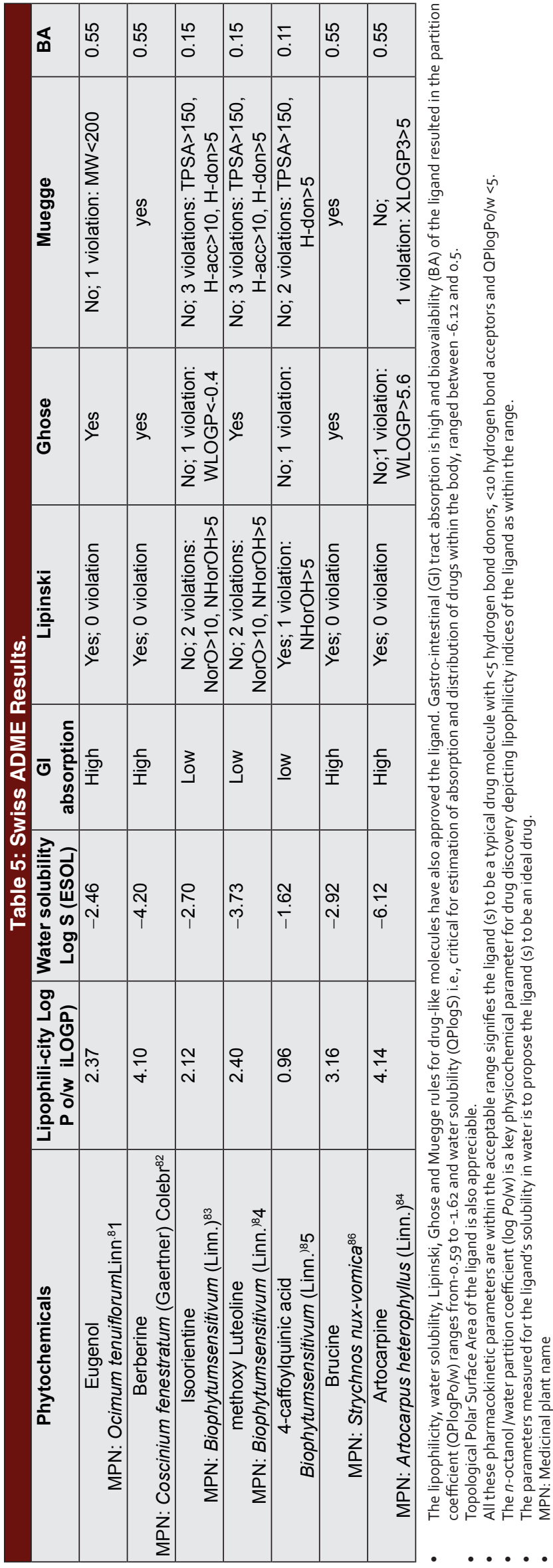




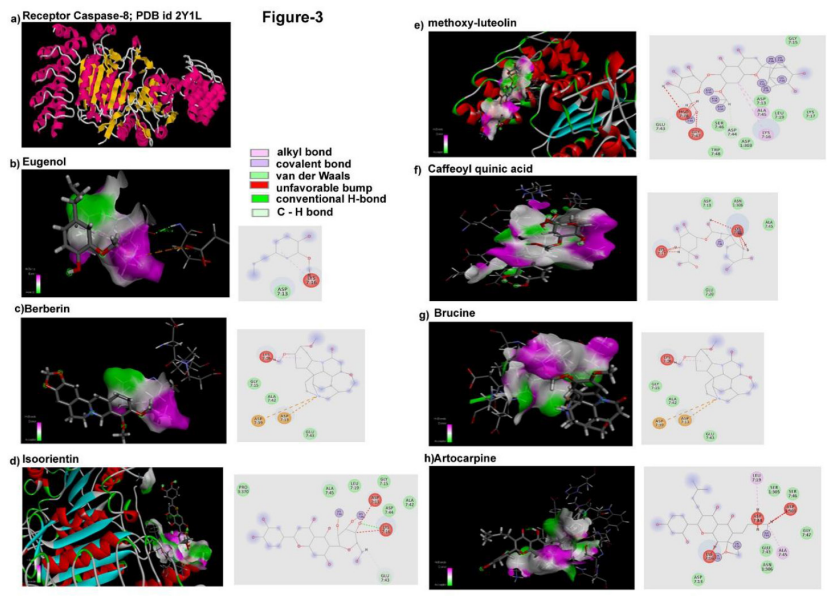

Figure 3: In silico docking of phytochemicals from important Kani tribe medicinal plants docked to receptor caspase-8 (PDB id 2Y1L).

(a) 2Y1L receptor caspase obtained from RCBS PDB;(b)Eugenol interaction with 2Y1L and estimated $\Delta \mathrm{G}(\mathrm{kcal} / \mathrm{mol})$ was $-6.03 ;$ (c) Berberine interaction with $2 \mathrm{Y} 1 \mathrm{~L}$ and estimated $\Delta \mathrm{G}(\mathrm{kcal} / \mathrm{mol})$ was -6.28 ; (d)Isoorientin interaction with $2 \mathrm{Y} 1 \mathrm{~L}$ and estimated $\Delta \mathrm{G}(\mathrm{kcal} / \mathrm{mol})$ was $-7.89 ;(\mathrm{e})$ methoxy Luteolin interaction with 2Y1L and estimated $\Delta \mathrm{G}(\mathrm{kcal} / \mathrm{mol})$ was -7.90 ; (f) Caffoylqunic acid interaction with 2Y1L and estimated $\Delta \mathrm{G}(\mathrm{kcal} / \mathrm{mol})$ was $-8.19 ;(\mathrm{g})$ Brucine interaction with $2 \mathrm{Y} 1 \mathrm{~L}$ and estimated $\Delta \mathrm{G}(\mathrm{kcal} /$ $\mathrm{mol}$ ) was $-8.94 \mathrm{and}(\mathrm{h})$ Artocarpin interaction with $2 \mathrm{Y} 1 \mathrm{~L}$ and estimated $\Delta \mathrm{G}(\mathrm{kcal} / \mathrm{mol})$ was -9.22 .

their apoptotic property as visualized by blebbing of the cells visualized (indicated by arrows) as early as at $24 \mathrm{hr}$ of treatment.

HeLa cells were visualized under CLSM for morphological changes induced by exposure to eugenol and berberine. In contrast to clear body observed in HeLa cells of the control group, cells exposed to eugenol $(500 \mathrm{~m} / \mathrm{mL})$ and berberine $(500 \mathrm{mg} / \mathrm{mL})$ exhibited the loss of these structural characteristics.

\section{Eugenol and berberine treatment Caused caspase-8 activation in HeLa Cells}

We tested whether eugenol and berberine-induced apoptosis was caspase- 8 dependent after staining with CaspGLOWTMFluorescein active Caspase- 8 staining kit was procured for detection of active Caspase- 8 in living cells. The FITC (fluorescent marker)-conjugated caspase-8 inhibitor, IETD-FMK permeabilized the cells. It bound to cytosolic active caspase- 8 irreversibly. FITC on the IETD-FMK was detected. Eugenol and berberine-treated HeLa cells exhibited a time-dependent increase in mean caspase-8fluorescence compared to control cells (Figure 4). For example, the caspase- 8 fluorescence in HeLa cells treated with $500 \mathrm{~m} / \mathrm{ml}$ eugenol and $500 \mu \mathrm{g} / \mathrm{mL}$ berberine was increased by approximately 7.9- and 6.5-fold, respectively compared to the control group (Figure 4g). The higher the capacity
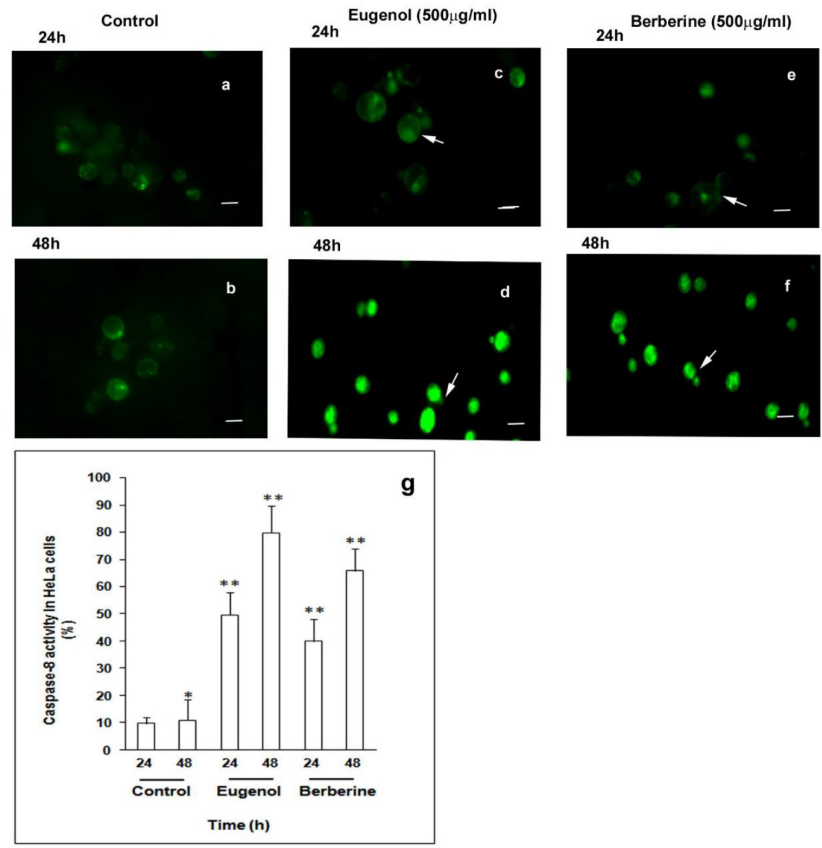

Figure 4: CaspGlow ${ }^{\mathrm{TM}}$ Fluorescein detection of caspase-8 activated inHeLa cells upon treatment with eugenol $(500 \mathrm{mg} / \mathrm{mL})$ and berberine $(500 \mathrm{mg} / \mathrm{mL})$ for $24 \mathrm{~h}$ and $48 \mathrm{~h}$.

Intracellular fluorescence of FITC on the IETD-FMK for all the samples was detected by Confocal Laser Scanning Microscope, LSM710 (Carl Zeiss, Germany). Control

HeLa cells (a, b); eugenol treatment for $24 \mathrm{~h}$ (c, d) and $48 \mathrm{~h}$ (e, f); berberine treatment for $24 \mathrm{~h}$ (c) and $48 \mathrm{~h}$ (e).Arrows indicate blebbing of the cells. Bar corresponds to 10 microm. Fluorescence was quantified $(\mathrm{g})$ as detailed in materials and methods. *Significant $(p<0.05)$ versuscontrol cells.

to activate caspase- 8 supports the apoptotic potential of the phytochemical.

\section{CONCLUSION}

Cancer onset could be attributed to several factors. Apart from epigenetic, environmental factors, dietary habits could not be excluded. ${ }^{15,69}$ Consumption of plants and their parts has been advocated since time immemorial. ${ }^{6}$ As the elicitation of oxidative stress by generation of reactive oxygen species (ROS), a product of mitochondrial oxidative phosphorylation in human body has been considered to be involved in initiation of cancer onset. ${ }^{70}$ Ample literature presently available, advocates on the merits of medicinal plants extracts and phytochemicals to alleviate cancer. ${ }^{39} \mathrm{~A}$ few of the reported plant extracts ${ }^{36,38}$ and phytochemicals ${ }^{71}$ have already shown anticancer activity at clinical trials. Phytochemicals at academic level identified from the present compilation at pre-clinical stage should be introduced for clinical studies. They could be used alone or augmented with chemotherapeutic drugs. Phytochemicals identified in the present compilation could act as proactive preventive anticancer dietary 
regime even in genetically predisposed individuals to cancer. $^{72}$ Thus, collaboration, guidance and support for herbal medicine use with prior systematic evaluation for cancer patients are needed as the dialogue between mainstream medicine and herbal medicine practitioners. An integration of herbal medicine into conventional cancer management strategies will aid in full realization of its value in cancer therapeutics. It could be a medico driven in comparison to a patient driven strategy.

\section{ACKNOWLEDGEMENT}

SS acknowledges the recognition of University of Mysore as an Institution of Excellence. The financial support from the Ministry of Human Resource Development, New Delhi, Govt. of India through UGC under UOM/IOE/RESEARCH/1/2010-11, dt 22-04-2010 project. The computational facility at the Bioinformatics Centre, Maharani Science College, Palace Road, Bengaluru, India was used during this work and it is gratefully acknowledged.

\section{CONFLICT OF INTEREST}

There is no conflict of interest and the authors declare the same.

\section{ABBREVIATIONS}

2Y1L: Caspase-8 of from Homo sapiens complex with DARP (dopamine releasing protein) in -8.4 from protein data bank; ADMET: Absorption, Distribution, Metabolism, Excretion, Toxicity; Alu elements: An Alu element is a short stretch of DNA originally characterized by the action of the Arthrobacter luteus $(A l u)$ restriction endonuclease; CARD: Caspase Recruitment Domain; CASP-8: CASP8 gene encodes Caspase- 8 protein; CED-3: Ced-3 is an executioner caspase (cysteine-dependent aspartate-directed protease); DARP: Dopamine releasing protein;FDA: US Food and Drug Administration; Flex and X, Surflex 20: Docking tools and programs have been developed for both academic and commercial applications; MALDI-TOF: Matrix-Assisted Laser Desorption/Ionization-Time Of Flight MALDI-TOF; NCI: The National Cancer Institute; WHO: The World Health Organization

\section{REFERENCES}

1. Nicholson DW, Thornberry NA. Caspases: Killer proteases. Trends Biochem Sci. 1997;22(8):299-306.

2. Parrish $A B$, Freel $C D$, Kornbluth $S$. Cellular mechanism controlling caspase activation and function. Cold Spring Harb Perspect Biol. 2013;5(6):1-5.

3. Kumar S. Caspase function in programmed cell death. Cell Death Differ. 2007;14(1):32-43.
4. Xavier TF, Kannan M, Lija L, Auxillia A, Kanthi A, Rose F, et al. Ethnobotanical study of Kani tribes in Thoduhills of Kerala, South India. J Ethnopharmacol. 2014;152(1):78-90.

5. Koehn FE. High impact of technologies for natural products screening. Prog Drug Res. 2008;65:177-210.

6. Atanasov AG, Waltenberger B, Wenzing EMP, Linder T, Wawrosch C, Uhrin $\mathrm{P}$, et al. Discovery and resupply of pharmacologically active plant-derived natural products: A review. Biotechnol Adv. 2015;33(8):1582-614.

7. Rodrigues T, Reker D, Schneider P, Schneider G. Counting on natural products for drug design. Nat Chem. 2016;8(6):531.

8. Olsson M, Zhivotovsky B. Caspases and cancer. Cell Death Differ. 2011;18(9):1441-9.

9. Teitz T, Wei T, Valentine MB, Vanin EF, Grenet J, Valentine VA, et al. Caspase 8 is deleted or silenced preferentially in childhood neuroblastomas with amplification of MYCN. Nat Med. 2000;6(5):529-35.

10. Ashley DM, Riffkin CD, Muscat AM, Knight MJ, Kaye AH, Novak U, et al. Caspase 8 is absent or low in many ex vivo gliomas. Cancer. 2005;104(7):1487-96.

11. Kim HS, Lee JW, Soung YH, Park WS, Kim SY, Lee JH, et al. Inactivating mutations of caspase-8 gene in colorectal carcinomas. Gastroenterol. 2003;125(3):708-15.

12. Soung $\mathrm{YH}$, Lee JW, Kim HS, Park WS, Kim SY, Lee JH, et al. Inactivating mutations of CASPASE-7 gene in human cancers. Oncogene. 2003;22(39):8048-52.

13. Kaufmann $\mathrm{SH}$, Lee $\mathrm{SH}$, Meng XW, Loegering DA, Kottke TJ, Henzing $\mathrm{AJ}$, et al. Apoptosis-associated caspase activation assays. Methods. 2008;44(3):262-72.

14. Cragg GM, Newman DJ. Plants as a source of anticancer agents. J Ethnopharmacol. 2005;100(1-2):72-9.

15. Bhaskaran K, Douglas I, Forbes H, Dos-Santos-Silva I, Leon DA, Smeeth L. Body-mass index and risk of 22 specific cancers: A population-based cohort study of $5 \cdot 24$ million UK adults. Lancet. 2014;384(9945):755-65.

16. Willett WC, Koplan JP, Nugent R, Dusenbury C, Puska P, Gaziano TA. Prevention of chronic disease by means of diet and lifestyle changes. In Disease control priorities in developing countries chapter $44,2^{\text {nd }}$ edition. Oxford University Press. 2006;833-50.

17. Wang $\mathrm{H}$, Khor TO, Shu L, Su Z, Fuentes $\mathrm{F}$, Lee JH, et al. Plants against cancer: A review on natural phytochemicals in preventing and treating cancers and their drug ability. Anticancer Agents Med Chem. 2012;12(10):1281-305.

18. Gavrilas LI, Ionescue C, Tudoran O, Lisencu C, Balacescu O, Miere D. The role of bioactive dietary components in modulating miRNA expression in colorectal cancer. Nutrients. 2016;8(10):590.

19. Pezzuto JM. Plant-derived anticancer agents. Biochem Pharmacol. 1997;53(2):121-33.

20. Cassileth BR. Evaluating complementary and alternative therapies for cancer patients. CA Cancer J Clin. 1999;49(6):362-75.

21. Aggarwal BB, Ichikawa H, Garodia P, Weerasinghe P, Sethi G, Bhatt ID, et al. From traditional Ayurvedic medicine to modern medicine: Identification of therapeutic targets for suppression of inflammation and cancer. Expert Opin Ther Targets. 2006;10(1):87-118.

22. Newman DJ, Cragg GM. Natural products as sources of new drugs over the 30 years from 1981 to 2010. J Nat Prod. 2012;75(3):311-35.

23. Wong FC, Tan ST, Chai TT. Phytochemical mediated protein expression profiling and the potential application in therapeutic drug target identification. Critical Rev Food Sci Nutr. 2016;56(Sup 1):S162-70.

24. Che E, Gao Y, Wan L, Zhang Y, Han N, et al. Paclitaxel/gelatin coated magnetic mesoporous silica nanoparticles: Preparation and antitumor efficacy in vivo. Microporous Mesoporous Mater. 2015;204:226-34.

25. Piktel E, Niemirowicz K, Watek M, Wollny T, Deptula P, Bucki R. Recent insights into nanotechnology-based drugs and formulations designed for effective anticancer therapy. J Nanobiotechnol. 2016;14(1):39.

26. Heiss E, Herhaus C, Klimo K, Bartsch H, Gerhäuser C. Nuclear Factor KB is a molecular target for sulforaphane-mediated anti-inflammatory mechanisms. J Biol Chem. 2001;276(34):32008-15.

27. Pledgie-Tracy A, Sobolewski MD, Davidson NE. Sulforaphane induces cell type-specific apoptosis in human breast cancer cell lines. Mol Cancer Ther. 2007;6(3):1013-21. 
28. Cornblatt BS, Ye L, Dinkova-Kostova AT, Erb M, Fahey JW, Singh K, et al. Preclinical and clinical evaluation of sulforaphane for chemoprevention in the breast. Carcinogenesis. 2007;28(7):1485-90.

29. Unnati S, Ripal S, Sanjeev A, Niyati A. Novel anticancer agents from plant sources. Chinese J Nat Med. 2013;11(1):16-23.

30. Solowey E, Lichtenstein M, Sallo S, Paavilainen H, Solowet E, LorberboumGalski H. Evaluating medicinal plants for anticancer activity. Sci World J. 2014;2014:1-2.

31. Jordan MA, Wilson L. Microtubules as a target for anticancer drugs. Nat Rev Cancer. 2004;4(4):253-65.

32. Risinger AL, Giles FJ, Mooberry SL. Microtubule dynamics as a target in oncology. Cancer Treat Rev. 2009;35(3):255-61.

33. Amin A, Muhtasib GH, Ocker M, Schneider-Stock R. Overview of major classes of plant-derived anticancer drugs. In J Biomed Sci. 2009;5(1):1-1.

34. Raza H, John A. Green tea polyphenol epigallocatechin-3-gallate differentially modulates oxidative stress in $\mathrm{PC} 12$ cell compartments. Toxicol Appl Pharmacol. 2005;207(3):212-20.

35. Newcomb EW. Flavopiridol: Pleiotropic biological effects enhance its anticancer activity. Anti Cancer Drug. 2004;15(5):411-9.

36. Zheng N, Dai J, Cao H, Sun S, Fang J, Li Q, et al. Current understanding on anti-hepatocarcinoma effects of xiao chai hu tang and its constituents. Evid Based Complement Alternat Med. 2013;2013:1-14.

37. Steuer-Vogt MK. The effect of an adjuvant mistletoe treatment program in resected head and neck cancer patients: A randomized controlled clinical trial. Eur J Cancer. 2001;37(1):23-31.

38. Tanaka S, Haruma K, Yoshihara M, Kajiyama G, Kira K, Amagase H, et al. Aged garlic extract has potential suppressive effect on colorectal adenomas in humans. J Nutr. 2006;136(3):821S-6S.

39. Atanasov AG, Waltenberger B, Wenzing EMP, Linder T, Wawrosch C, Uhrin P, et al. Discovery and resupply of pharmacologically active plant-derived natural products: A review. Biotechnol Adv. 2015;33(8):1582-614.

40. Muhtasib $\mathrm{GH}$. Emerging cytotoxic alkaloids in the battle against cancer: Overview of molecular mechanisms. Molecules. 2007;250:1-22.

41. Davis CD. Cellular cancer processes and their molecular targets for nutritional pre-emption of cancer. In: 'Bioactive compounds and cancer'. Humana Press. 2010;50-6.

42. Gunasinghe $\mathrm{S}$, Arambewela $\mathrm{L}$. The role played by plant sources in cancer therapy in Sri Lanka. J Indigenous Med. 2014;1-4.

43. Pan MH, Ghai G, Ho CT. Food bioactives, apoptosis and cancer. Mol Nutr Food Res. 2008;52(1):43-52.

44. Wang $\mathrm{H}$, Khor TO, Shu L, Su Z, Fuentes F, Lee JH, et al. Plants against cancer: A review on natural phytochemicals in preventing and treating cancers and their drug ability. Anticancer Agents Med Chem. 2012;12(10):1281-305.

45. Baliga MS, Venkatesh S, Mrinal S, Bala N, Palatty PL. Bioactive dietary factors and plant extracts in dermatology Part III. In 'Plant and Plant components and skin care. Humana Press. 2013;93-136.

46. Mund MD, Alam S. Khan UH, Tahir U, Zubair MS, Younas T, et al. Phytochemcials as complementary and laternative therapeutic formulations with potential proapoptotic effects on various cancerous cell lines: A literature survey. Focus Sci. 2016;2(2):1-5.

47. Sliwoski G, Kothiwale S, Meiler J, JrLowe EW. Computational methods in drug discovery. Pharmacol Rev. 2014;66(1):334-95.

48. Tung NH, Du GJ, Yuan CS, Shoyama $\mathrm{Y}$, Wang $\mathrm{CZ}$. Isolation and chemopreventive evaluation of novel naphthoquinone compounds from Alkanna tinctoria. Anticancer Drugs 2013;24(10):1058-68.

49. Bhattacharjee B, Chatterjee J. Identification of proapoptotic, antiinflammatory, anti-proliferative, anti-invasive and anti-angiogenic targets of essential oils in cardamom by dual reverse virtual screening an binding pose analysis. Asian Pac J Cancer Prev. 2013;14(6):3735-42.

50. Selvamangai G, Bhaskar A. Analysis of phytocomponents in the methanolic extract of Eupatorium triplinerve by GC-MS method. Int J Drug Dev Res. 2013;5:384-91.

51. Muthukala B, Sivakumari K, Ashok K. In silico docking of quercetin compound against the HeLa cell line proteins. Int J Curr Pharma Res. 2015;7(1):13-6.

52. Vaidya A, Jain AK, Kumar BRP, Sastry GN, Kashaw SK, Agarawal RK. CoMFA, CoMSIA, kNN, MFA and docking studies of 1,2,4-oxadiazole derivatives as potent caspase-3 activators. Arabian J Chem. 2017;10:S3936-46.
53. Putt KS, Chen GW, Pearson JM, Sandhorst JS, Hoagland MS, Kwon JT, et al. Small molecule activation of procaspase-3 to caspase-3 as a personalized anticancer strategy. Nat Chem Biol. 2010;2(10):543-50.

54. Kumar MS, Lainu KL, Aghila V, Purushothaman D, Gopal KV, Namboori PKK et al. Designing a promoter for a novel target site identified in caspases for initiating apoptosis in cancer cells. In Inf Commun Tech: Springer-Verlag Berlin Heidelberg. 2010;62-7.

55. Wu G, Robertson DH, Brooks CL. Detailed analysis of Grid-based molecular docking: A case study of CDOCKER-A CHARMm-based MD docking algorithm. J Comp Chem. 2003;24(13):1549-62.

56. Yap WH, Khoo KS, Lim SH, Yeo CC, Lim YM. Proteomic analysis of the molecular response of Raji cells to maslinic acid treatment. Phytomedicine. 2012;19(2):183-91.

57. Rufino-Palomares EE, Reyes-Zurita FJ, Garcia-Salgureo L, Mokhtari K, Medina PP, Lupianez JA, et al. Maslinic acid, a triterpenic anti-tumoral agent, interferes with cytoskeleton protein expression in HT29 human colon-cancer cells. J Proteomics. 2013;83:15-25.

58. Reyes-Zurita FJ, Rufino-Palomares EE, Medina PP, Garcia-Salgureo L, Peragon J, Cascante M, et al. Antitumor activity on extrinsic apoptotic targets of the triterpenoid maslinic acid in p53 deficient Caco-2 adenocarcinoma cells. Biochimie. 2013;95(11):2157-67.

59. Wong FC, Tan ST, Chai TT. Phytochemical mediated protein expression profiling and the potential application in therapeutic drug target identification. Critical Rev Food Sci Nutr. 2016;56(Suppl 1):S162-70.

60. Wang H, Yin H, Yan F, Sun M, Du L, Peng W, et al. Folate-mediated mitochondrial targeting with doxorubicin-polyrotaxane nanoparticles overcomes multidrug resistance. Oncotarget. 2015;6(5):2827.

61. Jiang L, Li L, He X, Yi Q, He B, Cao J, et al. Overcoming drug resistant lung cancer by paclitaxel loaded dual-functional liposomes with mitochondria targeting and $\mathrm{pH}$-response. Biomater. 2015;52:126-39.

62. Costa PM, Cardoso AL, Mendonça LS, Serani A, Custódia C, Conceição M, et al. Tumor-targeted chlorotoxin-coupled nanoparticles for nucleic acid delivery to glioblastoma cells: A promising system for glioblastoma treatment. Mol Ther Nucleic Acids. 2013;1-4.

63. Aslam MI, Patel M, Singh B, Jameson JS, Pringle JH. MicroRNA manipulation in colorectal cancer cells: From laboratory to clinical application. J Transl Med. 2012;10(1):128

64. Velasco G, Sanchez C, Guzman M. Anticancer mechanisms of cannabinoids. Curr Oncol. 2016;23(Suppl 2):S23.

65. Dubois MAL. Bioactive saponins with cancer related and immunomodulatory activity: Recent developments. Stud Nat Prod Chem. 2005;32:209-46.

66. Dubois MAL. Bioactive saponins with cancer related and immunomodulatory activity: Recent developments. In: Studies in Natural Products Chemistry: Bioactive natural products, Part L, Elsevier, Netherlands. 2005;32:209-46.

67. Das A, Harshadha K, Kannan DSK, Hari RK, Jayaprakash B. Evaluation of therapeutic Potential of eugenol-a natural derivative of Syzygium aromaticum on cervical cancer. Asian Pac J Cancer Prev. 2018;19(7):1977.

68. LuB, Hu M, Liu K, Peng J. Cytotoxicity of berberine on human cervical carcinoma HeLa cells through mitochondria, death receptor and MAPK pathways and in-silico drug-target prediction. Toxicol in vitro. 2010;24(6):1482-90

69. Habli Z, Toumieh G, Fatfat M, Rahal ON, Muhtasib GH. Emerging cytotoxic alkaloids in the battle against cancer: Overview of molecular mechanisms. Molecules. 2017;22(2):250.

70. Aykan NF. Red meat and colorectal cancer. Oncol Rev. 2015;9(1):288.

71. Panieri E, Santoro MM. ROS homeostasis and metabolism: A dangerous liason in cancer cells. Cell Death Dis. 2016;7(6):e2253.

72. Jiang L, Li L, He X, Yi Q, He B, Cao J, et al. Overcoming drug resistant lung cancer by paclitaxel loaded dual-functional liposomes with mitochondria targeting and $\mathrm{pH}$-response. Biomater. 2015;52:126-39.

73. Kischkel FC, Lawrence DA, Tinel A, LeBlanc H, Virmani A, Schow P, et al. Death receptor recruitment of endogenous caspase-10 and apoptosis initiation in the absence of caspase-8. J Biol Chem. 2001;276(49):46639-46.

74. Yoo NJ, Lee JW, Kim YJ, Soung YH, Kim SY, Nam SW, et al. Loss of caspase-2, -6 and -7 expression in gastric cancers. APMIS 2004;112:330-5.

75. Palmerini F, Devilard E, Jarry A, Birg F, Xerri L. Caspase 7 downregulation as an immunohistochemical marker of colonic carcinoma. Hum Pathol. 2001;32(5):461-7. 
76. Devarajan E, Sahin AA, Chen JS, Krishnamurthy RR, Aggarwal N, Brun AM, et al. Downregulation of caspase 3 in breast cancer: A possible mechanism for chemoresistance. Oncogene. 2002;21(57):8843-51.

77. Nakopoulou L, Alexandrou P, Stefanaki K, Panayotopoulou E, Lazaris AC Davaris PS. Immunohistochemical expression of caspase-3 as an adverse indicator of the clinical outcome in human breast cancer. Pathobiology. 2001;69(5):266-73.

78. Deeb D, Jiang H, Gao X, Al-Holou S, Danyluk AL, Dulchavsky SA, et al. Curcumin [1,7-bis(4-hydroxy-3-methoxyphenyl)-1-6-heptadine-3,5-dione; $\mathrm{C} 21 \mathrm{H} 2006$ ] sensitizes human prostatecancer cells to tumor necrosis factorrelated apoptosis-inducing ligand/Apo2L-induced apoptosisby suppressing nuclear factor-kappaB via inhibition of the prosurvival Akt signaling pathway. J Pharmacol Exp Ther. 2007;321(2):616-25.

79. Khan N, Adhami VM, Mukhtar H. Apoptosis by dietary agents for prevention and treatment of prostate cancer. Endocr Relat Cancer. 2011;17(1):R39-52.

80. Shailasree S, Venkataramana M, Niranjana SR, Prakash HS. Cytotoxic effect of $p$-coumaric acid on neuroblastoma, $\mathrm{N} 2 \mathrm{a}$ cell via generation of reactive oxygen species leading to dysfunction of mitochondria inducing apoptosis and autophagy. Mol Neurobiol. 2015;51(1):119-30.
81. Tuso PJ. Nutritional update for physicians: Plant based diets. Perm J. 2013;17(2):61.

82. Pattanayak P, Behera P, Das D, Panda SK. Ocimum sanctum Linn. A reservoir plant for therapeutic applications: An overview. Pharmacogn Rev. 2010;4(7):95.

83. Singh A, Bajpai V, Kumar S, Kumar KBR, Kumar B. Simultaneous quantification of protoberberine and aporphine alkaloids in different plant parts of Coscinium fenestratum (Gaertner) Colebr. By liquid chromatographyhybrid triple quadrupole/liner ion trap mass spectrometer. J Med Plants Studies. 2016;4(3):144-8.

84. Sakthivel KM, Guruvayoorappan C. Biophytum sensitivum: Ancient medicine, modern targets. J Adv Pharm Technol Res. 2012;3(2):83.

85. Yin W, Deng XK, Yin FZ, Zhang XC, Cai BC. The cytotoxicity induced by brucine from the seed of Strychnos nux-vomica proceeds via apoptosis and is mediated by cyclooxygenase 2 and caspase 3 in SMMC 7221 cells. Food Chem Toxicol. 2007;45(9):1700-8.

86. Lee CW, Hsu LF, Lee MH, Lee I, Liu JF, Chiang YC, et al. Extracts of Artocarpus communis induce mitochondria-associated apoptosis via pro-oxidative activity in human glioblastoma cells. Front Pharmacol. 2018;9:411.
PICTORIAL ABSTRACT

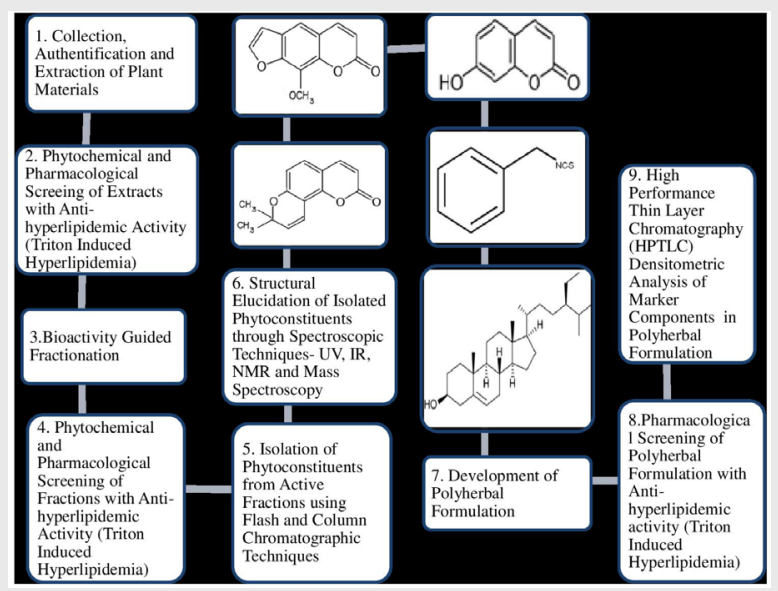

\section{SUMMARY}

- Phytochemicals with a capacity to activate caspases enhancing apoptotic capacity has been proven to be effective anticancer agents.

- Data on phtochemicals traditionally used to treat cancerous conditions and the scientific validation of caspase-activated apoptosis for this traditional application has been compiled. Internet assisted scientific literature was collected.

- Technological advancement has been included for identification of hit molecule and lead optimization.

- Eugenol and berberine were identified as phytochemicals with potential drug characteristics by both in silico and in vivo studies.

- The phytochemicals from important Kani tribal medicinal plants via in silico docking and in vivo studies identified could be explored at clinical trials.

Cite this article: Saqib A, Pattar S, Karigar CS, Sekhar S. Caspase Activators: Phytochemicals with Apoptotic Properties Targeting Cancer, a Health Care Strategy to Combat this Disease. Indian J of Pharmaceutical Education and Research. 2020;54(2s):s43-s55. 